\title{
Sosyal Paylaşım Sitelerinin Dijital Yerlilerin Bilgi Edinme ve Mahremiyet Anlayışına Etkisi
}

\author{
The Effects of Social Networking Sites on Understanding of \\ Information and Privacy of Digital Natives
}

\author{
Asiye KAKIRMAN YILDIZ*
}

\begin{abstract}
Öz
Literatürde 1980 ve sonrasında doğanlar dijital yerli olarak tanımlanmaktadır. Dijital yerlilerin en önemli özelliklerinden bir tanesi ve bunu tanımadıkları insanlar da dâhil olmak üzere, kendilerine ait bilgi, fotoğraf, veri vb. sosyal paylaşım sitelerinde başkalarıyla paylaşmakta bir sakınca görmemeleridir. Bunu bilgi edinmek ya da paylaşmak amacıyla yaptıklarını belirtseler de yeni neslin bilgi edinme ve mahremiyet anlayışııın sorgulanması gerekliliği ortaya çıkmıştır.

Bu çalışmada, Marmara Üniversitesi Bilgi ve Belge Yönetimi Bölümü (MÜBBY) öğrencilerinin birer dijital yerli olarak sosyal paylaşım sitelerini nasıl kullandıkları sorgulanmış ve neticesinde öğrencilerin bilgiedinme yaklaşımlarıve mahremiyet konusuna bakış açıları incelenmiştir. Çalışma kapsamında MÜBBY'de birinci eğitimde öğrenim gören 230 öğrenciye kapalı uçlu sorulardan oluşan anket uygulanmıştır. Anket sonuçları SPSS programına girilerek değerlendirilmiş ve sonuçlar buna göre yorumlanmıştır. Çalışma sonucunda, ankete katılan dijital yerlilerin bilgi edinme ve bilgi paylaşımı konusunda sosyal platformu sıklıkla kullandıkları ve yaklaşık yarısının sosyal platformda hareket ederken mahremiyet kavramını referans almadığı görülmüş̧ür.
\end{abstract}

Anahtar sözcükler: Dijital yerliler, Gizlilik, Bilgi edinme, Sosyal ağ

\section{Abstract}

Those born after 1980 are defined in literature as digital natives. The digital natives were literally born into a world of knowledge and technology. The most important characteristic of digital natives is that not only do they perfom more than one function on a single device simultaneously but that they also do not have any qualms about sharing personal information even with indviduals that they do not know online. Even though digital natives would argue that their aim is to simply share information, it is necessary to probe how the new generation's understanding of the concepts of obtaining information and privacy.

This study examined how students of the Department of Information and Records Management at the University of Marmara as digital natives used social networking sites and therefore examined the approach of students to obtanining information and their views on the issue of privacy. In this study, 230 students who are formal training at MÜBBY were surveyed

* Dr.; Marmara Üniversitesi Fen Edebiyat Fakültesi Bilgi ve Belge Yönetimi, İstanbul. (akakirman@marmara.edu.tr) 
a questionnaire consisting of close-ended questions. The survey results were entered the SPSS program and the results were evaluated according to SPSS results. End of the study, participated in the survey of the digital natives on the social platform are often used to obtain information and knowledge sharing, and about half of the digital natives while moving on the social platform had not seen the reference of the concept of privacy.

Keywords: Digital natives, Privacy, Information, Social networking

\section{Giriş}

Sosyal paylaşım sitelerinin en önemli özellikleri açık ve özgür olmasıdır. Açıklık ve özgürlük kültürüne dayanan bu ortamın kullanıcıları olan dijital yerliler, web teknolojilerini kullanarak hem bilgi edinmekte hem de istedikleri bilgileri istedikleri gibi özgürce paylaşabilmektedir.

Doğdukları andan itibaren adeta teknoloji bilgisiyle donatılmış olan dijital yerliler, kişisel ya da genel her türlü bilgi ve görüntülerini sosyal paylaşım sitelerinde yayınlamakta; bunu yapmakta da bir sakınca görmemektedirler. 1980 sonrasında doğan 30 yaş altı gençlerden oluşan dijital yerlilerin verileri paylaşırken neredeyse hiçbir çekince yaşamaması, mahremiyet duygusunun sorgulanmasını gerekli kılmaktadır.

Sosyal paylaşım sitelerinin etkinliğini gözardı etmek tabii ki mümkün değildir. Sadece eğlence ve paylaşım amacı ile değil birçok kişinin iş amaçlı ya da reklam amaçlı olarak da bu ortamları kullandığı görülmektedir. Hatta son Amerika Birleşik Devletleri başkanının seçimi kazanmasında en büyük desteğin bu sitelerdeki faaliyetleri olduğu konusunda haberlerin olduğu da bilinmektedir.

Ancak yapılan çalışmalara bakıldığında bağımlı bir şekilde internet kullananların yüz yüze iletişim kurdukları kişilerin sayısının, sosyal sitelerde görüştüklerinin yarısına denk geldiği görülmektedir. Nitekim ülkemizde 15 yaş ve üstü toplam 1.8 milyon kişinin internet kullandığı ve ayda ortalama 544 milyon saat vakit geçirildiği ve kişi başına aylık 30 saatlik bir internet kullanımının olduğu düşünülürse, bu gerçek gençlerin ve çocukların bilgi edinme ve bilgi aktarma ihtiyaçlarını nasıl temin ettikleri ve bunları ne kadar yoğun bir şekilde paylaştıkları sorusunu akla getirmektedir (comScore, 2012).

Yapılan bir başka çalışmada ise dijital yerlilerin ne yaptıklarının farkında olduklarını ve internete yükledikleri fotoğrafların yayın hakkını ihlal ettiklerinin bilincinde oldukları belirtilmektedir. Çalışmada Alman İletişim ve İnternet Hukuku Enstitüsü'nden Prof. Dr. Klemens Skibicki bu denli paylaşıma açık bir neslin oluşmasında medyanın etkili olduğunu savunarak, "dijital göçmenler (30 yaş üstü) ile dijital yerliler arasında büyük farklar var. Çünkü şimdiki nesil talkshowlarla, biri bizi gözetliyor tarzı programlarla büyüdü ve bu durum mahremiyetin sınırlarının esnek tutulmasına neden oldu" değerlendirmesinde bulunduğu belirtilmektedir (Schmidt, 2010). 
Bu çerçevede kişisel bilgilerin yasal yollarla güvence altına alınması gerekliliği düşüncesi doğabilir ancak, kişisel bilgileri ya da görüntüleri de sanal ortama taşıyanın kişinin bizzat kendisinin olduğu unutulmamalıdır. Yani aslında internet ortamına atılan en küçük bir kişisel veri o andan itibaren genele ait olmaktadır. Dolayısıyla mahremiyet duygusunu da kanunlarla, yasalarla belirlemek yerine vicdani bir hareketle korumak gerekmektedir. Bunun dışında kişinin her hangi bir katkısı olmaksızın yayılan kişisel bilgilerin ise elbette güvence altına alınması şarttır. Ancak bu çalışmada bahsedilen, kişilerin hiç tanımadıkları insanlarla bile özel bilgilerini paylaştıkları noktasından hareketle, mahremiyet duygusunun kişilerin hayatlarında hangi noktada durduğunu ve bu kişilerin bilgi edinme ihtiyaçlarını nasıl temin ettiklerini tespit edebilmektir.

\section{Dijital Yerlilerin Özellikleri}

Dijital medya ile büyümüş olan ve genellikle "net generation" olarak adlandırılan yeni neslin bilgi edinme alışkanlıkları ve yaklaşımları hakkında pek çok araştırma yayımlanmıştır. Bu araştırmalarda kişileri teknoloji ile yakınlığına göre dijital yerli ya da dijital göçmen olarak ayıran Marc Prensky'nin çalışmaları oldukça dikkat çekicidir.

Prensky (2001a; 2001b, 2009) “Dijital Yerliler Dijital Göçmenler" adlı çalışmasında bugünün öğrencilerinin öğrenme tarzlarının radikal bir biçimde değiştiğinden ve dijital yerli olan öğrencilere ders veren öğretmenlerinin dijital göçmen olarak kaldığından bahsetmektedir.

Tonta'nın da (2009) bu konuyu ele aldığı başka bir çalışmada, dijital göçmenlerin önce basılı kaynaklara ardından internete bakarken dijital yerlilerde bilgi edinme yaklaşımının tam tersi olduğu belirtilmektedir. Bilgiye hızla ulaşmak isteyen dijital yerliler metin yerine grafiği, bir makaleyi baştan sona okumak yerine kapsül halinde rastgele okumayı (örneğin, hipermetin ortamlarında bir yerden bir yere atlayarak okumayı), ciddi çalışmalar yapmak yerine oyunları tercih etmekte, pek çok işi aynı anda yürütebilmektedirler. Bilgisayarlar, ses ve video özellikleri olan cep telefonları, e-posta gibi dijital medya ve web ortamı yaşamlarının ayrılmaz bir parçasıdır (Prensky, 2001a; 2001b, 2009).

Dijital yerlilerin bilgi arama, kullanma ve yaratma yöntemleri de dijital göçmenlerinkinden belirgin bir biçimde farklıdır. Dijital göçmenler öncelikli olarak fiziksel kütüphaneyi kullanmayı tercih ederken dijital yerliler, sosyalleştiklerini düşündükleri sanal ortam üzerinden bilgiye erişmek istemektedirler (Tonta, 2009)

Son dönemlerde yapılan araştırmaların hemen hepsinde, dijital yerlilerin çoğunun internet üzerinden erişilemeyen kütüphaneleri kullanmadıklarına işaret edilmektedir. Kütüphane web siteleri yerine Facebook veya MySpace gibi sosyal ağ sitelerini kullanmaktadırlar. Bunun temel nedeni bu tür sosyal ağların“hızla web içinde web’ler haline gelmeleri, çeşitli hizmetler için tek bir dükkan" olmalarıdır. Sosyal ağ sistemleri, kullanıcılara sosyalleşmenin yanı sıra bilgi paylaşmak, binlerce uygulamayı çalıştırmak veya kendi içerik ve uygulamalarını yaratmak için sanal bir ortam sunmaktadır (Rayport, 2009). 


\section{Mahremiyet Kavramının Ifade Ettikleri}

Son dönemlerde gerek bütün dünyada gerekse ülkemizde boşanma oranlarının arttığı görülmektedir. Bu oranın eskiye göre büyük bir artış göstermesinin nedenleri arasında artık kadınların da ekonomik özgürlüğe sahip olması ve erkek egemenliğine boyun eğmemesi, ilk sırada gösterilmektedir.

Her ne kadar kadınların ekonomik özgürlüğe sahip olması toplumsal açıdan olumlu etkilere sahipse de bazı olumsuz gelişmeleri de beraberinde getirdiği açıktır. Okuldan geldiği zaman artık annesi de evde olmayan çocuk / genç (dijital yerli) kapıyı kendisi açmakta, yemeğini kendisi hazırlamakta (ki yemekten kastedilen genellikle fast-food tarzı yiyecekler olmaktadır) ve maalesef iletişim kurmak için etrafında kimse olmadığından sanal ortamda sosyalleşmeye çalışmaktadır. Bu davranışın bir müddet sonra doğallaşmasıyla birlikte yalnız, içine kapanık ve paylaşımını sosyal medya üzerinde gerçekleştiren bireyler yetişmektedir. Dolayısıyla bir insanla paylaşmak istediği bir sorununu ya da sırrını kendisine en yakın gördüğü arkadaşıyla; sosyal medyayla paylaşmakta ve hem sosyolojik hem de psikolojik ihtiyaçlar neticesinde mahremiyet duygusunu tamamen saf dışı bırakmaktadır.

Bunun dışında ailevi değerlerin zayıflaması da artık kişilerin kendilerini sanal ortamda ifade etmesine zemin hazırlamaktadır. Ailevi değerlerin zayıflamasında elbette medyanın etkisini göz ardı etmek mümkün değildir. Dört duvar arasında yaşanması gereken evlilik kurumunun artık ekran karşısındaki herkes tarafından izlenebilir olması; evlendikten sonra çocuk sahibi olmak gibi ahlâki bir değerin yerini "şu anda evlenmeyi düşünmüyoruz, çocuk olursa belki" mantığının alması ve en önemlisi annebabası ayrı olan çocuk ve gençlerin sayısının, yani boşanma oranlarının her geçen gün artması kişileri boşluğa itmekte ve bu boşluk sanal âlemde hiç tanınmayan insanlarla doldurulmaya çalışılmaktadır. Öyle ki bu yalnızlık duygusu sadece gençlerde değil 30 yaşın üstündeki evlenmemiş kişilerde de görülmektedir.

Bir gazeteye ait pazar ekinde yapılan bir ankette, 30 yaşının üstünde olan evlenmemiş kadınlara neden evlenmedikleri sorulmakta; evlenmemenin artı ve eksi yönlerini değerlendirmeleri istenmektedir. Anket sonuçlarına göre, kadınların evlenmemeyi özgürlük olarak görmesi oldukça dikkat çekicidir. Ancak yine aynı grup içinde "kendimi yalnızlıktan evdeki çamaşır makinesiyle konuşurken buluyorum" diyenlerin olduğu da görülmektedir. Yine aynı grup üyelerinden sosyalleşmek için sanal ortamı kullananların oranının oldukça yüksek olduğu da görülmüştür (Sabah Pazar, 2012).

Türkiye'de yapılan bir çalışmada, dijital göçmenlerin yaş değerlerinin yükseldikçe, bilgisayar kullanım oranlarının düştüğü belirtilmektedir. Şekil 1'de bu bilgiyi destekleyen veriler yer almaktadır. Şekilde internet ve bilgisayarın en çok dijital yerliler tarafından kullanıldığı ve yaş değerleri yükseldikçe kullanım oranlarının düştüğü görülmektedir. (Türkiye İstatistik Kurumu [TÜIK], 2011). Ancak Amerika'da yapılan bir çalışma, bu konuda çok çarpıcı sonuçlar ortaya koymaktadır (OCLC, 2011). 


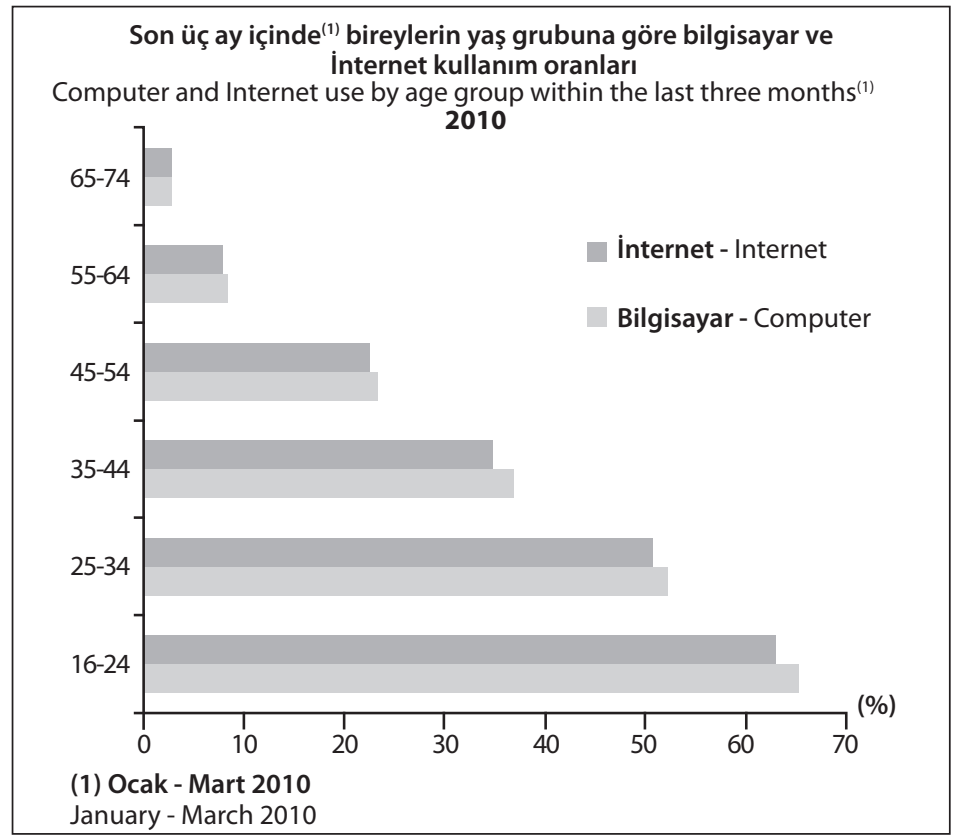

Şekil 1. Bireylerin Yaş Grubuna Göre Bilgisayar ve İnternet Kullanımı (TÜIK, 2011. s.94)

OCLC tarafından hazırlanan raporda 2007 ile 2010 yılları arasında yapılan bir takım istatistiklere yer verilmiş ve bu istatistiklerden sosyal medya platformunu kullananların artık sadece gençlerden oluşmadığı sonucu çıkmıştır. Yapılan çalışmaya göre, sosyal medya platformunun katılımcıları 14 ile 65 yaş ve üstünden oluşmaktadır. Bahsedilen yıllar arasında sosyal medyanın kullanımı ile ilgili değişim oranı ise oldukça dikkat çekicidir. Buna göre, zaten dijital yerli olan gençlerin her geçen gün sosyal platformda olduğunu görmek doğal bir gelişme. Ancak dikkat çeken ayrıntı, 45-64 yaş arası ile 65 yaş ve üstü kişilerin sosyal medya kullanımındaki muazzam artış. Verilere göre, bu yaş aralığındaki kişilerin sosyal platformu kullanım oranları 3 yıl içerisinde ortalama olarak \%250 artmıştır (OCLC, 2011).

Oldukça yüksek olan bu rakam, artık sadece gençlerin değil orta yaş ve üstü kişilerin de sanal iletişimde oldukça vakit harcadığını göstermektedir. Bu rakamlar, mahremiyet çalışmalarının istikameti açısından önemli ipuçları da sunmaktadır.

\section{Sosyal Platformun Tercih Edilme Sebebi}

Coğrafi, fiziksel ve ekonomik engelleri ortadan kaldırması nedeniyle, gerçek hayatta girilmesi mümkün olmayan gruplara girip, kendilerini daha rahat ifade edebilmeleri bu sitelerin dijital yerliler arasında popüler hale gelmesini sağlamıştır. Bir süre öncesine 
kadar daha çok bilgisayar oyunları ya da eğitim çalışmaları için internete giren çocukların da, sosyal paylaşım sitelerinin artmasıyla beraber geçler gibi sanal ortama daha çok ilgi gösterdiği de bir gerçektir.

Web 2.0 teknolojilerini kullanan en iyi sosyal ağlardan biri olan Facebook, e-posta gönderme, anında mesajlaşma, fotoğraf, müzik ve video paylaşma hizmetlerinin yanı sıra, yaklaşık bir milyon farklı kişi tarafından geliştirilen 300.000'den fazla uygulamaya erişim sağlamaktadır. Kullanıcılar Facebook sitesinden ayrılmadan Amazon'dan alış veriş yapabilmekte, OCLC'nin WorldCat kataloğunu tarayabilmekte, kullandıkları diğer sosyal ağlar (örneğin, Linkedln) ve paylaşım siteleriyle (örneğin, Slideshare) Facebook arasında bağlantı sağlayabilmekte ve Facebook'a gönderdikleri mesajları aynı anda diğer sosyal ağlarda veTwitter gibi mikro-günlük (microblogs) sitelerinde deyayımlayabilmektedirler. Facebook'un aktif kullanıcı sayısı 2011 Ağustos ayı itibariyle 700 milyon civarındadır. Bu kullanıcıların yarısı her gün Facebook kullanmakta ve Facebook üzerinde günde altı milyar dakika (yaklaşık dört milyon gün) harcamaktadırlar. Bu kullanıcılar Facebook'a her ay iki milyar fotoğraf, 14 milyon video yüklemekte, haftada iki milyar içerik (e-posta, bağlantı, haber, not, fotoğraf, vd.) paylaşmaktadırlar. Cep telefonları aracılığıyla Facebook'a erişen 65 milyon kullanıc bulunmaktadır (Rayport, 2009).

Bu rakamlara bakıldığında aslında bütün gerçekler görülmektedir. Neredeyse bütün vaktini bilgisayar başında geçiren gençlerin elbette insan insana iletişim kurmak için doğal ortamı kalmamaktadır. Bu bazen yalnızıktan bazen anlaşılmama duygusundan bazen de ailenin çocuğu üzerinde etkisinin olmamasından kaynaklanabilir. Ancak altı çizilmesi gereken en önemli ayrıntı ailenin güçlü ve kuşatıcı olmasının çocuk ve gençte de etkisini gösterdiğidir. Kendisiyle ilgilenildiğini gören dijital yerli mutlaka bu ilgiye cevap verecektir.

\section{Sosyal Paylaşım Sitelerinin Çocuklarda, Gençlerde ve Ailedeki Etkisi}

Bilgisayar oyunları ve sosyal paylaşım sitelerinin, özellikle çocukları ve ergenleri psikososyal gelişim açısından olumsuz etkilediği görülmektedir. Gerçek yaşamda akranlarla oynanan oyunların ve ilişkilerin yüz yüze olması, duyguların doğrudan paylaşılması, çocukların hem kendi kültürlerini öğrenmelerine hem de yaratıcılıklarının gelişmesine olanak sağlamaktadır.

Son dönemde oluşan sanal iletişim yollarıla gerçek yaşama ayrılan zaman azalmakta; çocuklar ve gençler gelişimleri açısından kendilerine rol model olabilecek kişilerle yüz yüze iletişim kurmamakta; giderek yalnız ve içe dönük hale gelmektedirler.

Nitekim, sosyal paylaşım sitelerine ayrılan vaktin artması ile dijital yerliler hiçbir zahmete katlanmadan, dünyanın hangi noktasında olduğu önemli olmaksızın istedikleri bilgiye ulaşabilmekte, yeni arkadaşlıklar kurup bunları kısa sürede tüketmekte ve bunun sonucunda da sabırsız, çabuk sıkılan, tatmin duygusu olmayan birer yetişkin olmaktadırlar. 
Yapılan bir araştırmada özellikle kendi kimliğinden ve sosyal konumundan memnun olmayan gençlerin, olanı değil olmasını istedikleri ideal kimliklerini sanal ortamlarda oluşturdukları tespit edilmiştir. Gerçek olmayan ve maskeli biçimde kurulan ilişkiler gençlerin gerçek kimliklerinin onay ve kabulünün zorlaşmasına ve yüz yüze iletişim gerektiren yetişkinler dünyasına adım attıklarında iletişim ve kendini ortaya koyma konularında çatışma yaşamalarına neden olabilmektedir (Şalom, 2012).

Bir başka önemli araştırmanın sonuçlarında ise, sosyal paylaşım sitelerinin ailelerin yapısına ve sosyal dokuya zarar verdiği tespit edilmiştir. Yüz yüze gelip de konuşamayacak birçok insan, kaygı duymadan internette rahat rahat konuşabilmekte ancak ilişkinin sınırını belirlemekte zorluk çektiği görülmektedir (Sosyal paylaşım siteleri soruşturması, 2011).

Sanal âlemdeki paylaşımın son yıllarda artan boşanmalar üzerindeki etkisine bakıldığında ise durum daha net anlaşılmaktadır: Araştırmalarda boşanmayı düşünen her dört kişiden birinin kararını vermesine internette yapılan sanal sohbetler ve paylaşım sitelerinin sebep olduğu gösterilmiştir. Aldatıldığını düşünen her iki kişiden biri eşinin kendisini internette tanıştığı birisiyle aldattığına inanmaktadır. ABD'de ise her üç boşanmanın birinde boşanma nedeni olarak internet bağımlılığının gösterildiği tespit edilmiştir. Bu tespite göre eşe ayrılacak zaman bilgisayarın başında geçirilmekte, ardından eşler birbirlerinden soğumaya ve uzaklaşmaya başlamakta ve sonunda da bu durum çiftleri aynı evde yaşayan iki yabancı haline getirmektedir. Sürekli sanal âlemde gezinme sonucu yaşanan depresyon, mutsuzluk ve tatminsizlik ise aileye olumsuz yansıyacak bir başka sonuç olarak karşımıza çıkmaktadır (Sosyal paylaşım siteleri soruşturması, 2011).

\section{Araştırmanın Alanı ve Kapsamı}

Evren Marmara Üniversitesi Bilgi ve Belge Yönetimi Bölümü'nde (MÜBBY) 2011-2012 Eğitim Öğretim yılında eğitim gören 470 öğrenciden oluşmakla birlikte çalışma evreni, MÜBBY'de, 2011-2012 akademik yılı bahar döneminde, birinci öğretimde eğitim gören 230 öğrenciden (1, 2, 3 ve 4. sınıf) oluşmaktadır. Onlardan bilgi edinme ihtiyaçlarını nasıl karşıladıklarını ve mahremiyet çerçevesinde sosyal medya platformunu nasıl kullandıklarını tespit etmeyi sağlayacak kapalı uçlu sorulara cevap vermeleri istenmiştir. Anket cevapları SPSS 15 programına girilmiş ve sonuçlar yorumlanmıştır.

Bu çalışmada yer alan sorular, dijital yerli olarak adlandırılan grup olan 1980 ve sonrası doğanları temsil etmesi açısından, MÜBBY'de eğitim gören öğrencilere uygulanmıştır. Çalışmaya katılan öğrencilerin doğum tarihleri 1987-1994 yılları arasındadır.

$\mathrm{Bu}$ alan çalışması yüz yüze anket yöntemi kullanılarak gerçekleştirilmiştir. Çalışma kapsamında belirlenen örneklem sayısına dâhil olan öğrencilere ulaşana kadar anket yapma işlemi devam etmiştir. Anketler, öğrencilere ders kayıtları, ders öncesi, öğle 
tatili gibi fiziksel ve psikolojik rahatlıkları göz önünde bulundurularak dağıtılmış ve aynı gün toplanmıştır. Öğrenciler tarafından doldurulan anketlerden 30 tanesi eksik ya da özensiz doldurulmaları nedeniyle değerlendirmeye alınamamıştır. Dolayısıyla çalışma kapsamında tam ve net olan 200 anket değerlendirilebilmiştir.

\section{Problemin Tanımlanması}

Bütün dünyada olduğu gibi maalesef ülkemizde de son yıllarda belirgin bir biçimde ahlak erozyonu gözlemlenmektedir. Bu erozyonun oluşumunda kişilerin "mahremiyet" duygusunun zedelenmiş olması en önemli faktörlerden biri olarak görülmektedir. "Mahremiyetsiz" insanların çoğalmasında şüphesiz ki bu insanlar tarafından sosyal medyanın çok aktif bir biçimde kullanılıyor olması önemli bir ayrıntıdır. Dolayısıyla sosyal medya, ya da sosyal paylaşım sitelerinin kişilerin zihinlerini nasıl etkilediği tartışılması gereken bir problem haline gelmiştir.

Sosyal paylaşım siteleri, sadece ülkemizde değil bütün dünyada etkisi tartışılmayacak derecede, insanları her alanda etkilemektedir. Ancak, yaşları 18-24 arasında değişen dijital yerlilerin, sosyal medya ortamındaki etkilere daha açık oldukları düşülmektedir. Sosyal medya şüphesiz doğru ve yerinde kullanıldığında zaman ve emek bakımından önemli tasarruflar sağlamaktadır. Ancak, bilgi edinmeye çalışırken mahremiyetin sınırlarının da zorlandığı görülmektedir. Bu durum hem bir gereksiz bilgi kalabalıklığı hem de maneviyat değerlerini zedeleyici bir sonuç ortaya çıkarmaktadır. Bu noktada sorulması gereken sorular şunlar olmalıdır:

$\diamond$ Sosyal paylaşım siteleri dijital yerlilerin bilgi edinme ve mahremiyet anlayışını etkilemekte midir?

$\diamond$ Dijital yerliler için mahremiyet kavramının önemi nedir?

$\diamond$ Dijital yerlilerin bilgi edinme yaklaşımı nasıldır?

\section{Çalışmanın Amacı}

Bu çalışmada, dijital yerli olarak adlandırılan gençlerin mahremiyet konusuna bakış açısı, bilgi edinme yaklaşımları ve sosyal paylaşım sitelerinin bu konuları ve dijital yerlilerin bakış açılarını nasıl etkilediğini tartışmak amaçlanmıştır.

\section{Çalışmanın Hipotezi}

"Dijital yerlilerin mahremiyet konusunda hassas ve sağduyulu oldukları şüphelidir ve sosyal paylaşım siteleri dijital yerlilerin bilgi edinme ve mahremiyet anlayışını etkilemektedir" hipotezinden hareketle bu çalışma ele alınmıştır. 


\section{Bulgular ve Yorum}

Çalışmanın bu bölümünde ankete katılan öğrencilerin mahremiyet anlayışı, bilgi edinme intiyacını temin etme biçimleri ve sosyal paylaşım sitelerinin hayatlarının ne kadarını kapsadığı anket sonuçlarına bağlı olarak tespit edilecek ve bu anketlerin yorumlanması gerçekleştirilecektir.

Ankete katılan bireylerin cinsiyete göre dağılımı incelenmiş, katılımcıların 52'sinin erkek, 148'inin kız öğrencilerden oluştuğu belirlenmiştir. Araştırmada ankete katılan öğrencilerin kütüphaneyi son bir yılda bilgi edinmek amacıyla fiziksel olarak kaç kez kullandıkları belirlenmeye çalışılmıştır. İlgili veriler Şekil 2'de sunulmuştur.

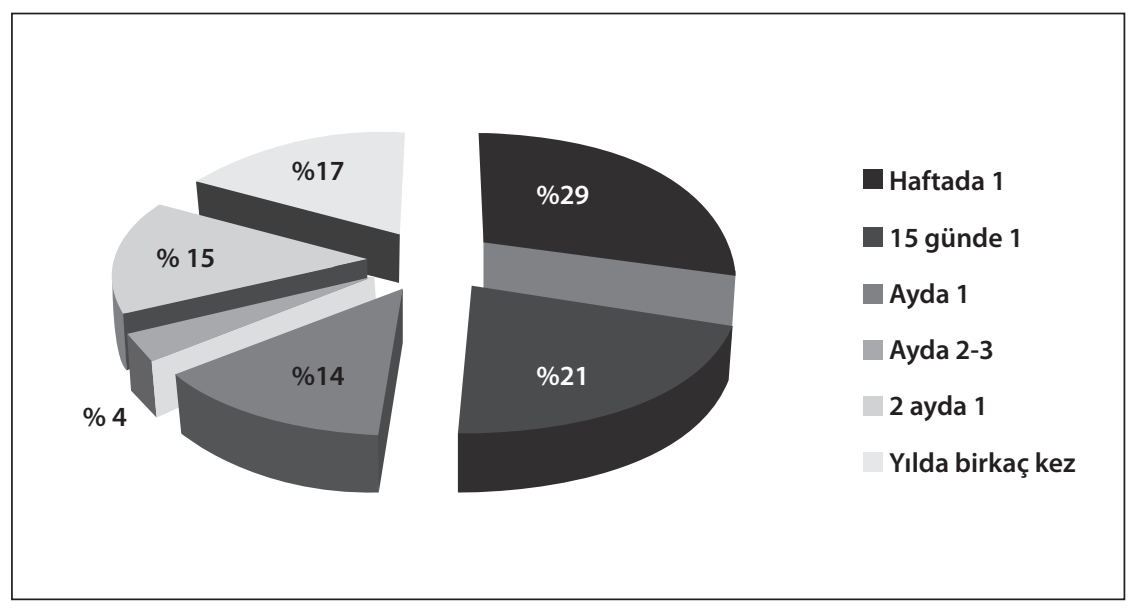

Şekil 2. Fiziksel Kütüphane Kullanımı

Şekil 2'ye göre kütüphaneyi fiziksel olarak kullananların sayısının hiç de azımsanmayacak oranda olduğu görülmektedir. Nitekim öğrencilerin \%29'u haftada 1; \%21'i ise 15 günde 1 kütüphaneye gitmektedir. Dolayısıyla öğrencilerin yaklaşık yarısının 10 günde 1 kütüphaneye gittiğini belirtmek yanlış olmayacaktır. Kütüphaneye yılda birkaç kez gidenlerin oranının \%17 olması da azımsanmayacak bir rakamdır. Ancak bu öğrencilerin sayısının çok olmasını dijital ortamın kullanımına bağlamak yanlış bir çıkarım olacaktır. Nitekim aşağıda da görüleceği üzere dijital ortamı yılda birkaç kez kullananların oranı \%11'dir.

Çalışmaya katılan öğrencilerin kütüphaneyi son bir yılda bilgi edinmek amacıyla web üzerinden kaç kez kullandıklarını belirlemeye yönelik veriler Şekil 3'de yer almaktadır. 


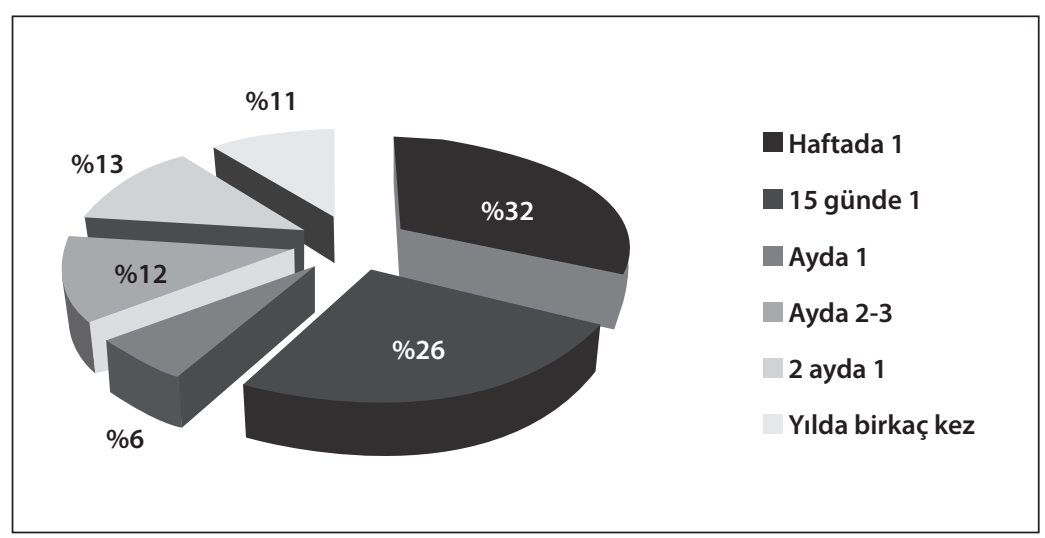

Şekil 3. Web Üzerinden Kütüphane Kullanımı

Dijital yerlilerin kütüphaneleri mekândan ziyade web üzerinden kullanması beklenmektedir. Bir diğer deyişle dijital yerlilerin kütüphaneleri fiziksel olarak kullanmadıkları ve artık kütüphaneye gitmedikleri belirtilmektedir. Ancak Şekil 3'de de görüldüğü gibi kütüphaneyi fiziksel olarak kullanmaları ile dijital olarak kullanmaları arasında pek bir fark yok gibidir. Şekil 2 ile Şekil 3 birlikte değerlendirildiğinde, öğrencilerin \%32'si haftada 1 gün kütüphaneyi web üzerinden kullanırken aynı grubun $\% 29$ 'u fiziksel olarak kullanmaktadır. Yine öğrencilerin $\% 26$ 's 15 günde 1 dijital kütüphaneyi kullanırken \%21'i fiziksel kütüphaneyi kullanmaktadır.

Tabii ki ortalama sonuçlara bakıldığında kütüphanenin dijital olarak kullanımının fiziksel olarak kullanımına göre daha yüksek olduğu muhakkaktır. Teknolojik gelişmelere paralel bir şekilde değişen ortamda, zahmetsiz olan dijital kullanımın zahmetli olan fiziksel kullanıma göre daha fazla olması doğaldır. Ancak bu sonuçlar, aynı öğrencilerin "dijital melez" (Kakırman Yıldız, 2012) davranışı sergilediğini ispatlaması açısından önemlidir.

Ankete katılan öğrencilerin sosyal medyaya (facebook, twitter, vb.) yönelik düşüncelerini yansıtan veriler Şekil 4'te gösterilmektedir. 


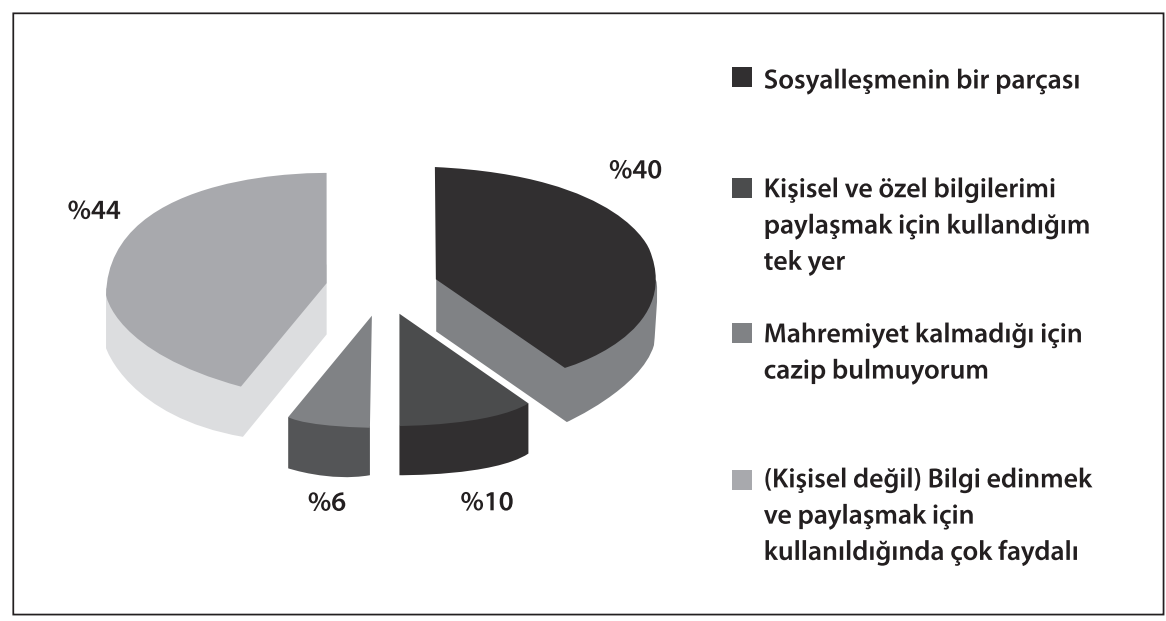

Şekil 4. Sosyal Medyaya Yönelik Düşünceler

Anket sonuçlarına göre 200 öğrencinin \%40'ı dijital medya ortamını sosyalleşmek için önemli görmekte; \%44'ü ise bilgi alışverişi için uygun ve önemli bulmaktadır. Buna mukabil ankete katılanların \%10'unun sosyal medya platformunu kişisel ve özel bilgilerini paylaştıkları yer olarak göstermesi ve \%40'ının sosyalleşmek için önemli bir platform olarak değerlendirmesi, sosyal medya ortamlarının gençler üzerindeki etkisini sosyolojik ve psikolojik açıdan değerlendirmeyi gerektirmektedir.

Mahremiyet kavramının sorgulandığı bu tablo daha da detaylı ele alındığında, kız öğrencilerin \%5'i erkek öğrencilerin ise \%1'i mahremiyet sınırları aşıldığı için sosyal medya ortamında olmayı cazip bulmadığını belirttiği görülmektedir. Mahremiyet sınırlarının aşıldığını düşünenlerin oranının oldukça düşük olması, dijital yerlilerin bu konuya bakışını yansıtması bakımından iyi okunmalı ve analiz edilmelidir. Kızöğrencilerin \%3'ü erkek öğrencilerin ise \%1'i kişisel bilgilerini paylaştıkları tek yerin sosyal medya platformu olduğunu ifade etmiştir. Yine aynı öğrencilerin kütüphaneyi gerek fiziksel gerekse dijital olarak hiç kullanmadıkları tespit edilmiştir. Sosyal medya platformunu sosyalleşmenin bir parçası olarak gören dijital yerlilerin oranı \%40'dır. Bu öğrencilerin aynı zamanda düzenli birer kütüphane kullanıcısı oldukları da görülmektedir. Ankete katılan kız öğrencilerin \%62'si erkek öğrencilerin ise \%34'ü kişisel bilgiler olmadığı sürece sosyal medyanın bilgi alışverişi için ideal bir ortam olduğunu belirtmiştir.

Ankete katılan öğrenciler için dijital kütüphane kullanımının (uzaktan erişim) önemli olup olmadığını belirlemeye yönelik veriler Şekil 5'te sunulmuştur. 


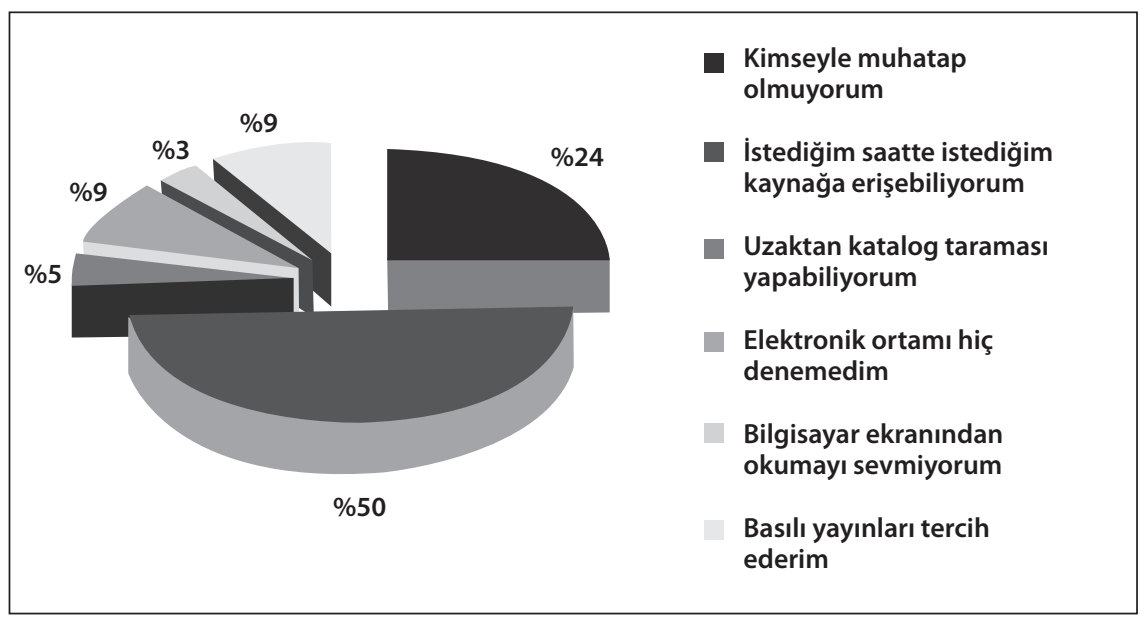

Şekil 5. Dijital Kütüphane Kullanımı (Uzaktan Erişim)

Şekil 5 verileri aslında, sosyo-psikolojik olarak ele alınması gereken bir başka göstergedir. Nitekim öğrencilerin \%24'ünün kimseyle muhatap olmamayı önemli görmesi oldukça dikkat çekicidir. Bu sonuç dijital ortamda bilgi edinme yaklaşımının insanları asosyal varlıklar haline getirip getirmediği sorusunu da akla getirmektedir. Bunun yanı sıra öğrencilerin yarısının dijital kütüphane kullanımını zaman kısıtlaması olmadığı için önemsediği görülmektedir. Ancak yine de elektronik ortamı hiç denemeyenlerin olduğu (dijital göçmen davranışı) ve basılı yayınların tercih edilmesi de dikkate alınması gereken sonuçlar içermektedir.

Ankete katılan öğrenciler bilgi edinmek için sadece dijital kütüphaneyi tercih etme sebebi olarak ilk sırada istediği anda istediği bilgiye erişim imkânını göstermiştir. İkinci sırada ise kimseyle muhatap olmak zorunda kalmamalarını göstermişlerdir. İkinci sırada yer alan bu cevap öğrencilerin insan iletişiminden, yüz yüze iletişimden kaçmaya başladıklarını göstermesi açısından dikkate alınmalıdır. Bir insanın böyle bir cevabı verebilmesi için yalnızlığı, içe dönüklüğü, kısacası insansız hayatı tercih etmesi gerekmektedir. Her ne kadar \%24 düşük bir oranmış gibi görünse de bu rakamın zaman içinde yükseleceği muhakkaktır. Tabii bu durum hem sosyal hem de psikolojik olarak gerek kişisel gerekse toplumsal düzlemde uzun vadeli sorunlara da yol açacaktır.

\section{Sonuç}

BBY öğrencilerinin kütüphaneyi sık kullanmaları ve bilgi ihtiyaçlarını temin etmek için ilk başvuracakları yerin kütüphaneler olması beklenmektedir. Ancak, kütüphaneyi bilgi edinme ihtiyaçları için gerek dijital gerekse fiziksel olarak kullananların oranı \%54'dür. Geri kalan \%46 ise Google ya da Facebook gibi siteler üzerinden araştırma yapmaktadır. 
Web 2.0 uygulamalarının ortaya çıkmasıyla kütüphane kullanıcıları giderek daha gelişmiş bilgi hizmetlerine gereksinim duymaya, kütüphanelere gitmek yerine web teknolojilerini kullanarak kendi verilerini yönetmeye, başka kaynaklardan buldukları zengin bilgileri kendi bilgileriyle bütünleştirmeye ve bu bilgileri başkalarıla paylaşmaya başlamışlardır. Dolayısıyla dijital yerlilerin artık bilgi edinme ihtiyaçlarını dijital olarak temin etmeye başladığını belirtmek gerekmektedir.

Yapılan araştırmalar, insanların, hayatlarının bütün detaylarını tüm dünyayla paylaşmalarını sağlayan Facebook ve Twitter gibi sosyal paylaşım sitelerinin mahremiyet ve gizliliği ortadan kaldırdığını, utanma duygusunu yok ettiğini ve kıskançlık duygusunu derinleştirdiğini iddia etmektedir. Kısacası sosyal ağlar ve sosyal medyanın özellikle dijital yerliler üzerinde oldukça etkili olduğu ve onların yaşam tarzlarını, alışkanlıklarını, eğlenme ve öğrenme biçimlerini tamamen etkilediği görülmektedir. Nitekim Facebook, kurumsal misyonunu "dünyanın insanlarını düzenlemek" olarak açıklamıştır. Oldukça çarpıcı olan bu misyon bildiriminin Facebook tarafından başarıldığı ve başarılmaya devam edeceği kullanıcı sayısının her geçen gün artmasıyla kanıtlanmıştır. Bu araştırmalar göz önüne alındığında bu sitelerin sınırlı ve amacına yönelik kullanımının ve bu bilincin geliştirilmesi gerekliliğinin ne kadar önemli olduğu görülmektedir.

Facebook kriterlerine göre düzenlenecek olan insanların bir müddet sonra bütün alışkanlık, inanç, aidiyetlik duygusu ve değerlerinin de aynı düzenlemeye tâbi olacağı muhakkaktır. Bir müddet sonra ise birbirinin kopyası olan zihinlerin çoğaldığını görmek hiç de şaşırtıcı olmamalıdır. Bu nedenle öncelikle anne babaların çocuklarına gerçekten yeterince vakit ayırıp ayırmadıkları konusunu vicdani bir şekilde sorgulaması gerekmektedir. Her bireyi kendine özgü vasıflarıyla yetiştiren ve insan ve toplum sevgisini de aşılayan eğitimlere, paylaşımlara ve en önemlisi sohbetlere ihtiyaç vardır. Nitekim bizim kültürümüz, sohbet geleneği olan bir kültürdür.

Sanal âlemde yetişen dijital yerlilerin çocuklarının çok daha büyük sorunlarla karşılaşmaması için, hem anne babalara hem de eğitmenlere önemli görevler düşmektedir. Özellikle anne babaların etkili iletişim yoluyla çocuklarını sanal ortamdan korumaya çalışılması gerekmektedir. Çocuğu tabii ki sürekli izlemek mümkün olmayacaktır ancak o bilincin verilmesi kontrol etmekten çok daha önemli görülmelidir. Nitekim bu çalışmadan çıkan sonuçlarda dijital yerli olarak nitelendirilen grubun sosyal medyayı hem kendini ifade etme, hem bilgi paylaşımı, hem de sosyalleşmek için ideal bir ortam olarak gördüğü anlaşılmaktadır. Dijital yerlilerin sosyal medya ortamına bu anlamı yüklemesi aslında onların gittikçe bireyselleştiğinin ve insansız iletişime geçtiğinin bir göstergesidir. 


\section{Kaynakça}

comScore (2012). 31 Mayıs 2012 tarihinde http://www.comscore.com adresinden erişilmiştir.

Erkuş, A. (2005). Bilimsel araştırma sarmalı. Ankara: Seçkin Yayınevi.

Kakırman Yıldız, A. (2012). Dijital yerliler gerçekten yerli mi yoksa dijital melez mi? Journal of Academic Social Science Studies, 5(6), 819-833.

OCLC (2011) Perceptions of libraries, 2010: Context and community: A report to the OCLC membership. Dublin, Ohio: OCLC.

Prensky, M. (2001a). Digital natives, digital immigrants. On The Horizon, 9(5), 1-6. 2 Haziran 2012 tarihinde http://www.marcprensky.com/writing/prensky\%20-\%20digital\%20natives,\%20 digital\%20immigrants\%20-\%20part1.pdf adresinden erişildi.

Prensky, M. (2001b). Digital natives, digital immigrants, Part II: Do they really think differently? On the Horizon, 9(6), 1-6. 2 Haziran 2012 tarihinde http://www.marcprensky.com/writing/ prensky\%20-\%20digital\%20natives,\%20digital\%20immigrants\%20-\%20part2.pdf adresinden erişildi.

Prensky, M. (2009). H. sapiens digital: From digital natives to digital wisdom. Innovate: Journal of Online Education, 5(3). 30 Mayıs 2012 tarihinde http://www.innovateonline.info/index. php?view=article\&id=705 adresinden erişildi.

Rayport, J. F. (2009). Social networks are the new web portals. 2 Haziran 2012 tarihinde http:// www.businessweek.com/technology/content/jan2009/tc20090121_557202.htm adresinden erişildi.

Sabah Pazar. (2012). 27 Mayıs 2012 tarihinde http://www.sabah.com.tr/Pazar adresinden erişildi.

Schmidt, F. (2010). Dijital yerli misiniz, göçmen mi? 29 Mayıs 2012 tarihinde http://www.dw.de/ dijital-yerli-misiniz-g\%C3\%B6\%C3\%A7men-mi/a-5902258 adresinden erişildi.

Sosyal Paylaşım Siteleri Soruşturması (2011). 2 Haziran 2012 tarihinde http://www.uhim.org/ images/rapor/1301669887.pdf adresinden erişildi.

Şalom (2012). Sanal âlem fayda mı zarar mı? 1 Haziran 2012 tarihinde http://www.salom.com.tr/ newsdetails.asp?id=79299\#.ULhhPuQidBo adresinden erişildi.

Tonta, Y. (2009). Dijital yerliler, sosyal ağlar ve kütüphanelerin geleceği. Türk Kütüphaneciliği, 23(4), 742-768.

Türkiye İstatistik Kurumu. (2011). Türkiye istatistik yıllığı, 2011 özeti: Istatistiklerle Türkiye. 6 Haziran 2012 tarihinde http://www.tuik.gov.tr/IcerikGetir.do?istab_id=5 adresinden erişildi. 